\title{
The relationship between height and diameter trees of Scots pine (Pinus sylvestris L.) and the extent of crown defoliation in the Kampinos National Park
}

\author{
Pawet Przybylski ${ }^{1} \bowtie$, Lukasz Tyburski ${ }^{2}$, Vasyl Mohytych ${ }^{1}$ \\ ${ }^{1}$ Forest Research Institute, Department of Silviculture and Genetics of Forest Trees, Braci Leśnej 3, Sękocin Stary, \\ 05-090 Raszyn, Poland, phone: +48227150337, e-mail: p.przybylski@ibles.waw.pl \\ ${ }^{2}$ Kampinos National Park, Department of Science and Nature Monitoring, Tetmajera 38, 05-080 Izabelin, Poland
}

\section{Abstract}

Forests in Kampinos National Park contain some of the most valuable tree populations in Poland. Particularly interesting are stands of Scots pine (Pinus sylvestris L.) that are more than 130-years-old. Periodic observations of the health of tree crowns in these stands facilitates a wide range of research investigations. This article evaluates statistical relationships between allometric features of trees and the occurrence and severity of crown defoliation.

Observations were made of 5 pine populations in 2017 and 2019, in which detailed data were collected for 250 trees. The percentage loss of the assimilation apparatus and level of stand damage were calculated.

The results revealed a significant increase in defoliation between 2017 and 2019. The deterioration of crown condition was particularly evident on the most fertile sites. The degree of crown damage was not correlated with tree height or diameter. The greatest increase in defoliation between 2017 and 2019 was observed for the most severely damaged trees growing on fertile sites.

This study contributes analyses aimed at correlating the allometric features of a stand with its health. Such information is valuable as it describes the status of the analysed stands, as well as providing information about how trees have responded to environmental conditions. In this study, crown defoliation coincided with a period of drought in Poland, which appears to have affected pine stands. For these reasons, the results are of both scientific and practical value.

\section{KEY WORDS}

Scots pine, health condition, defoliation, Kampinos Forest

\section{INTRODUCTION}

The Kampinos National Park (KNP) protects valuable natural tree populations in Poland, which occur on dune and marsh strips, with a distinctive complex of inland dunes (Zgorzelski and Pawłowska 2003). Within KNP are stands of varied age, species and area, with some tree populations more than 130 years old (mature forests). The total area of mature forests in KNP is about six thousand hectares (Tyburski 2015). Although hu- 
man activity has affected forests in KNP over the centuries (Heymanowski 1969), in these mature stands, ecological processes take place naturally. Due to the uniqueness and natural condition of mature stands of Scots pine (Pinus sylvestris L.) in KNP, attempts were made to increase the understanding of these, by implementing a project entitled 'Genetic characteristics of the common pine stands in the Kampinos National Park' in 2017-2019, in which defoliation was evaluated, among other things.

The assessment of crown defoliation is used in monitoring programmes carried out in Poland and abroad (Jaszczak 1995; Sierota 1995). They use the defoliation criterion as one of the elements of forest health assessment (Lech 1995). Defoliation is also one of the effects of drought, which is associated with moisture deficits affecting pine stands in Poland, especially since 2015. Drought can lead to, among other things, fungal infection and attacks by insects feeding in tree crowns (Lehner et al. 2006).

A tree's crown class (also called biosocial position), for example, dominant, co-dominant, intermediate, suppressed, and its crown development (e.g., from fully developed to partly dead) are expressed in the classification system developed by Kraft. Crown class can influence the level of defoliation a tree experiences, a result confirmed by Wójcik (2000), Dobbertin and Brang (2001), and Jaszczak (2000 and 2005). Trees suffering the greatest defoliation tend to be those in Kraft class 3 , and the difference between the average rate of defoliation of trees in Kraft classes 1 and 2 is statistically significant (Jaszczak and Miotke 2009). The level of defoliation also depends on the age of the stand (Jaszczak and Miotke 2009). Borecki and Wójcik (1996) found that defoliation is greater in older stands. In contrast, Jaszczak and Miotke (2009) found that older stands experience less defoliation than younger ones.

The photosynthetic efficiency of trees has been shown to vary with a number of aspects of tree physical size, including tree height, trunk diameter, crown structure, root system size, and so on. Photosynthetic capacity is influenced by both the size of the photosynthetic apparatus, which in trees is reflected by the size of the crown (Dubravac 2003, 2005; Jaszczak 2001; Urban et al. 2009), and by photosynthetic efficiency (Borowski 1966; Turski et al. 2015), that is, the amount of assimilate produced per unit of light energy the tree receives. In Poland, studies were also conducted on how increases in stem diameter (Dudek 1969) and tree volume (Lemke 1968; Zajączkowski 1973) relate to crown properties. To our knowledge, there is no work published that discusses the relationship between the level of crown defoliation, tree breast height diameter (Dbh) and height.

This paper examines the relationship of height and diameter with the extent of crown defoliation in pine trees in mature forests in the Kampinos National Park. We also analysed changes in the level of defoliation in these pine stands between 2017 and 2019.

\section{Material AND MEthods}

The research was carried out in KNP on research plots located in five areas: Czerwińskie Góry, Wilków, Granica, Sieraków and Wiersze (Fig. 1-6) like Tyburski and Przybylski (2018). All plots contained Scots pine over 130 years old, growing in forest habitat classified as mesic mixed coniferous, mesic coniferous or mesic mixed forest. Detailed data on the type of forest habitat

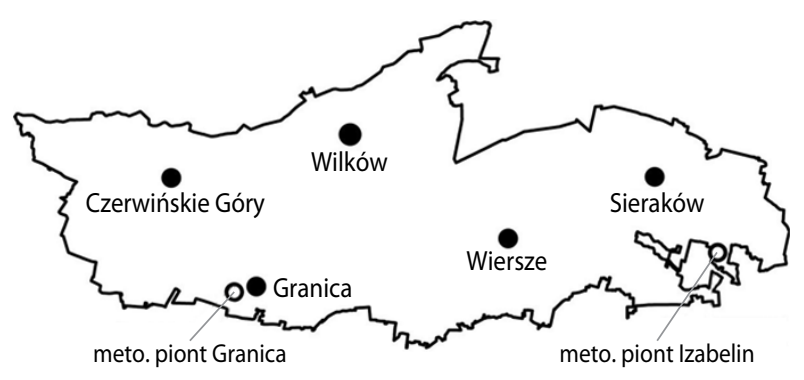

Figure 1. Map of the distribution of research areas and meteorological measurement stations in Kampinos National Park

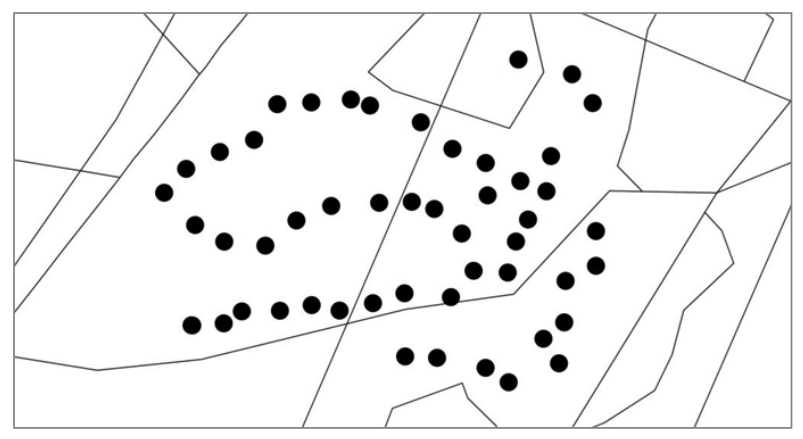

Figure 2. Distribution of trees in the Sieraków site 
and the average age of the analysed populations were published by Tyburski and Przybylski (2018). The re-

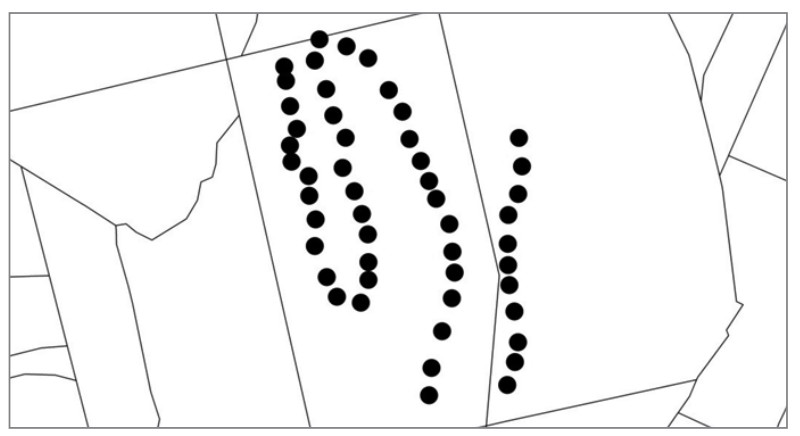

Figure 3. Distribution of trees in the Wiersze site

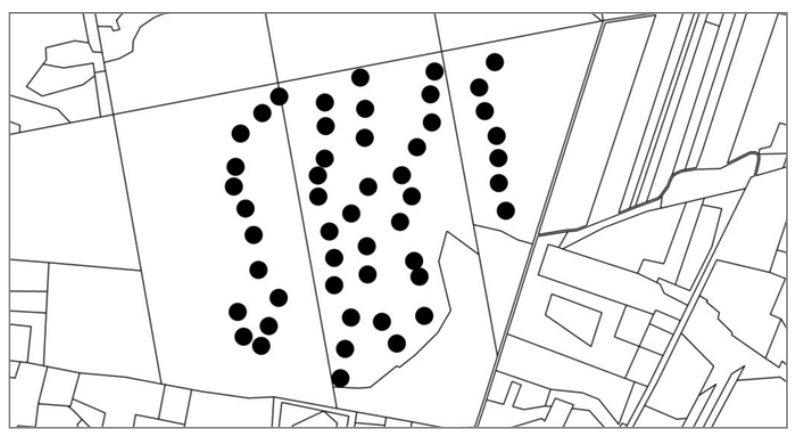

Figure 4. Distribution of trees in the Granica site

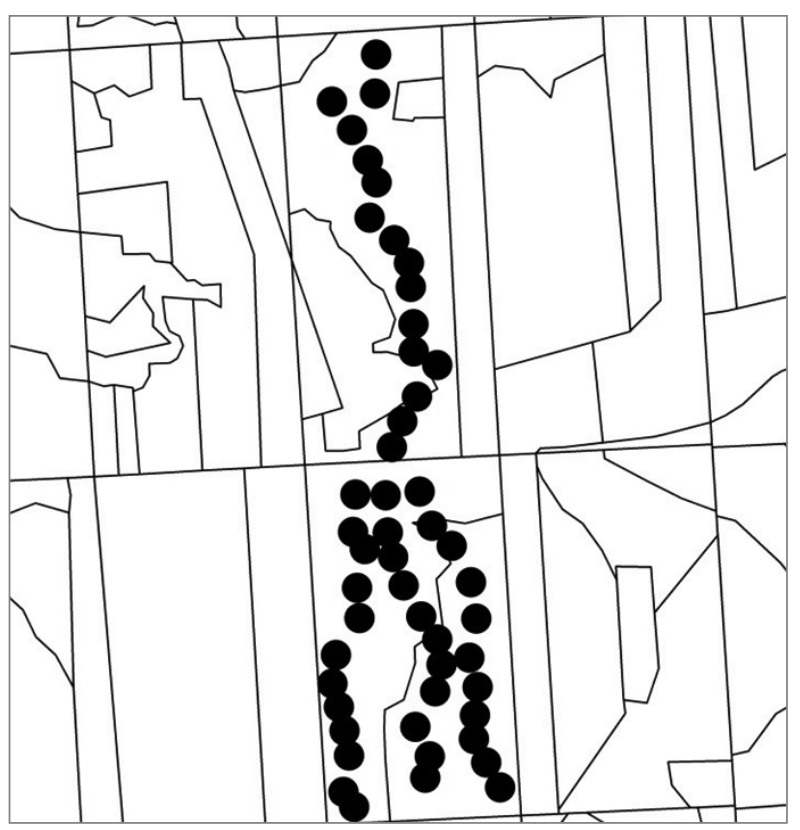

Figure 5. Distribution of trees in the Wilków site search plots were selected in a way that takes into account the diversity of the oldest stands and the total area of the park.

Fifty trees were sampled in each stand selected for analysis. The distance between sample trees was equivalent to at least the average stand height.

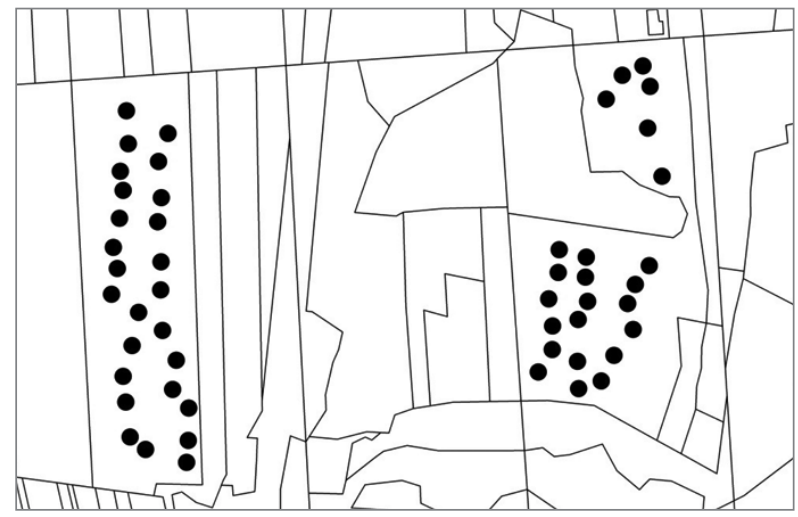

Figure 6. Distribution of trees in the Czerwińskie Góry site

In 2017 and 2019, the crown health of all sample trees was assessed twice a year. The assessment was based on the adapted methods for forest assessment carried out as part of the State Environmental Monitoring, as described by Tyburski and Przybylski (2016).

During field work in 2017, the height of all sample trees was measured using a Vertex ultrasonic hypsometer, with an accuracy of $\pm 0.2 \mathrm{~m}$. Diameter was measured at breast height $(1.30 \mathrm{~m})$ with an accuracy of $\pm 0.2 \mathrm{~cm}$. Meteorological data (2008-2018) describing average annual temperature and total annual rain-

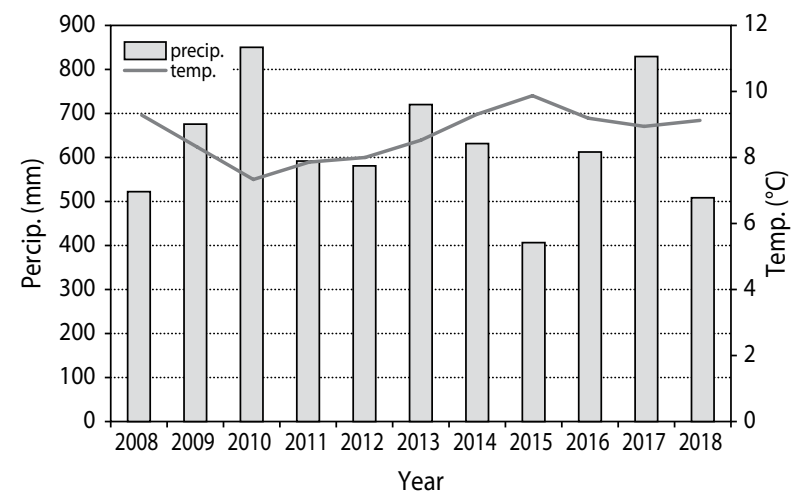

Figure 7. Average total annual precipitation and mean annual temperature at meteorological stations located in Izabelin and Granica, from 2008-2018 (KNP data) 
Table 1. Defoliation in 2017 and 2019 in Scots pine populations and mean height and diameter

\begin{tabular}{|c|c|c|c|c|c|c|c|c|c|c|c|c|}
\hline \multirow{2}{*}{ Population } & \multicolumn{2}{|c|}{ Czerwińskie G. } & \multicolumn{2}{|c|}{ Granica } & \multicolumn{2}{|c|}{ Sieraków } & \multicolumn{2}{|c|}{ Wiersze } & \multicolumn{2}{|c|}{ Wilków } & \multicolumn{2}{|c|}{ All populations } \\
\hline & mean & sd & mean & sd & mean & sd & mean & sd & mean & sd & mean & $\mathrm{sd}$ \\
\hline Defoliation_2017 & 38.6 & 9.0 & 46.2 & 9.0 & 37.7 & 7.9 & 38.4 & 10.8 & 38.2 & 8.6 & $39.8 * * *$ & 9.6 \\
\hline Defoliation_2019 & 41.1 & 11.9 & 47.0 & 10.0 & 38.9 & 7.5 & 40.1 & 12.2 & 40.0 & 10.4 & $41.6^{* * *}$ & 10.9 \\
\hline Height & 28.8 & 3.6 & 30.6 & 4.3 & 22.8 & 2.5 & 27.3 & 2.5 & 28.5 & 2.5 & $27.6 * * *$ & 4.1 \\
\hline $\mathrm{DBH}$ & 58.9 & 7.0 & 64.3 & 10.6 & 54.9 & 8.2 & 48.4 & 5.8 & 61.5 & 10.0 & $57.6 * * *$ & 10.1 \\
\hline
\end{tabular}

*** statistically significant difference $(\mathrm{p}<0.001)$.

fall were collected at permanent weather stations in the KNP (Fig. 7).

Data from these observations were used to calculate an average percentage loss of assimilation apparatus $\left(\mathrm{P}_{\mathrm{k}}\right)$, with an accuracy of $\pm 5 \%$ according to the Jaszczak formula (1995), based on which the tree stand was categorised as one with assimilation apparatus having an appropriately lower density $\left(\mathrm{A}_{\mathrm{k}}\right)$ :

1) up to $10 \%\left(\mathrm{~A}_{\mathrm{k}}=0\right)$,

2) $15 \%-25 \%\left(\mathrm{~A}_{\mathrm{k}}=1\right)$,

3) $30 \%-60 \%\left(\mathrm{~A}_{\mathrm{k}}=2\right)$,

4) $65 \%-95 \%\left(\mathrm{~A}_{\mathrm{k}}=4\right)$.

Crown dieback, expressed as the degree of loss of the assimilation apparatus $\left(\mathrm{A}_{\mathrm{k}}\right)$, was used to calculate the degree of tree stand thinning with the Dmyterko formula (1994), and the latter degree allowed determination of the level of stand damage $\left(\mathrm{A}_{\mathrm{u}}\right)$ on the following scale: undamaged $\left(A_{u}<0.50\right)$, very slightly damaged $\left(\mathrm{A}_{u}\right.$ 0.51-1.00), slightly damaged $\left(\mathrm{A}_{u}\right.$ 1.01-1.50), moderately damaged $\left(\mathrm{A}_{u}\right.$ 1.51-2.00), severely damaged $\left(A_{u} 2.01-2.50\right)$, and very severely damaged $\left(\mathrm{A}_{\mathrm{u}}>2.51\right)$.

Statistical analyses were conducted for assimilation apparatus assessments. ANOVA analysis and a posthoc Tukey's test were carried out using the 'laercio' library (Silva, 2015), while correlation analyses were conducted with the 'psych' library (Revelle, 2018), both using the ' $R$ ' environment (R Core Team 2018).

\section{Results}

Based on the assessment of the level of defoliation, crown condition was found to have deteriorated between 2017 and 2019 in $21.6 \%$ of the sampled trees:

- defoliation increased by $5-10 \%$ in 37 trees,
- defoliation increased by $15-20 \%$ in 7 trees,

- defoliation increased by $25-30 \%$ in 2 trees.

The highest increase in defoliation was observed in the stand at Czerwińskie Góry, where the crown condition of 15 trees deteriorated. Over the study period, one dead tree was reported in the stand at Wiersze. The average level of defoliation of each stand was significantly higher (Tab. 1). The stand at Granica had

Table 2. Significant differences in defoliation and tree size across Scots pine populations from five stands. Populations with different letters within columns differ significantly according to Tukey's test

\begin{tabular}{|l|c|c|c|c|}
\hline \multicolumn{1}{|c|}{ Population } & $\begin{array}{c}\text { Defolia- } \\
\text { tion_2017 }\end{array}$ & $\begin{array}{c}\text { Defolia- } \\
\text { tion_2019 }\end{array}$ & Height & Dbh \\
\hline Granica & $\mathrm{a}$ & $\mathrm{a}$ & $\mathrm{a}$ & $\mathrm{a}$ \\
\hline Czerwińskie G. & $\mathrm{b}$ & $\mathrm{ab}$ & $\mathrm{ab}$ & $\mathrm{ab}$ \\
\hline Wiersze & $\mathrm{b}$ & $\mathrm{b}$ & $\mathrm{b}$ & $\mathrm{c}$ \\
\hline Wilków & $\mathrm{b}$ & $\mathrm{b}$ & $\mathrm{ab}$ & $\mathrm{a}$ \\
\hline Sieraków & $\mathrm{b}$ & $\mathrm{b}$ & $\mathrm{c}$ & $\mathrm{b}$ \\
\hline
\end{tabular}

Table 3. The loss of assimilation apparatus $\left(\mathrm{P}_{\mathrm{k}}\right)$ and the level of stand damage $\left(\mathrm{A}_{\mathrm{u}}\right)$ based on the level of defoliation of trees in 2017 and 2019

\begin{tabular}{|l|c|c|c|}
\hline \multicolumn{1}{|c|}{ Population } & Number of trees & $\mathrm{Pk} \%$ & $\mathrm{Au}$ \\
\hline Czerwińskie G. & 50 & 2.5 & 0.06 \\
\hline Granica & 50 & 1.5 & 0.04 \\
\hline Sieraków & 50 & 1.2 & 0.02 \\
\hline Wiersze & 50 & 1.7 & 0.04 \\
\hline Wilków & 50 & 1.8 & 0.04 \\
\hline Mean & 50 & 1.74 & 0.04 \\
\hline
\end{tabular}


the highest level of defoliation, while the least defoliation was recorded at Sieraków (Tab. 1). In 2017 and 2019, the defoliation rate differed significantly among individual plots (Tab. 1). In the analysis of homogeneous groups, a significant deterioration in the condition of the Czerwińskie Góry population was observed (Tab. 2). Populations with the highest level of assimilation apparatus loss are among the tallest and largest diameter among the examined stands (Tab. 1 and 2).
Average loss of the assimilation apparatus was $1.74 \%$, with the highest value in Czerwińskie Góry (2.5) and lowest in Sieraków (1.7) (Tab. 3). Further analyses carried out using the Dmyterko formula (1994) indicated that all populations were categorized as undamaged (Tab. 3).

Across all sampled trees, the correlation between defoliation rate and either height or diameter at breast height of the trees was not significant (Fig. 8). A weak correlation (0.31) was found between height and diam-
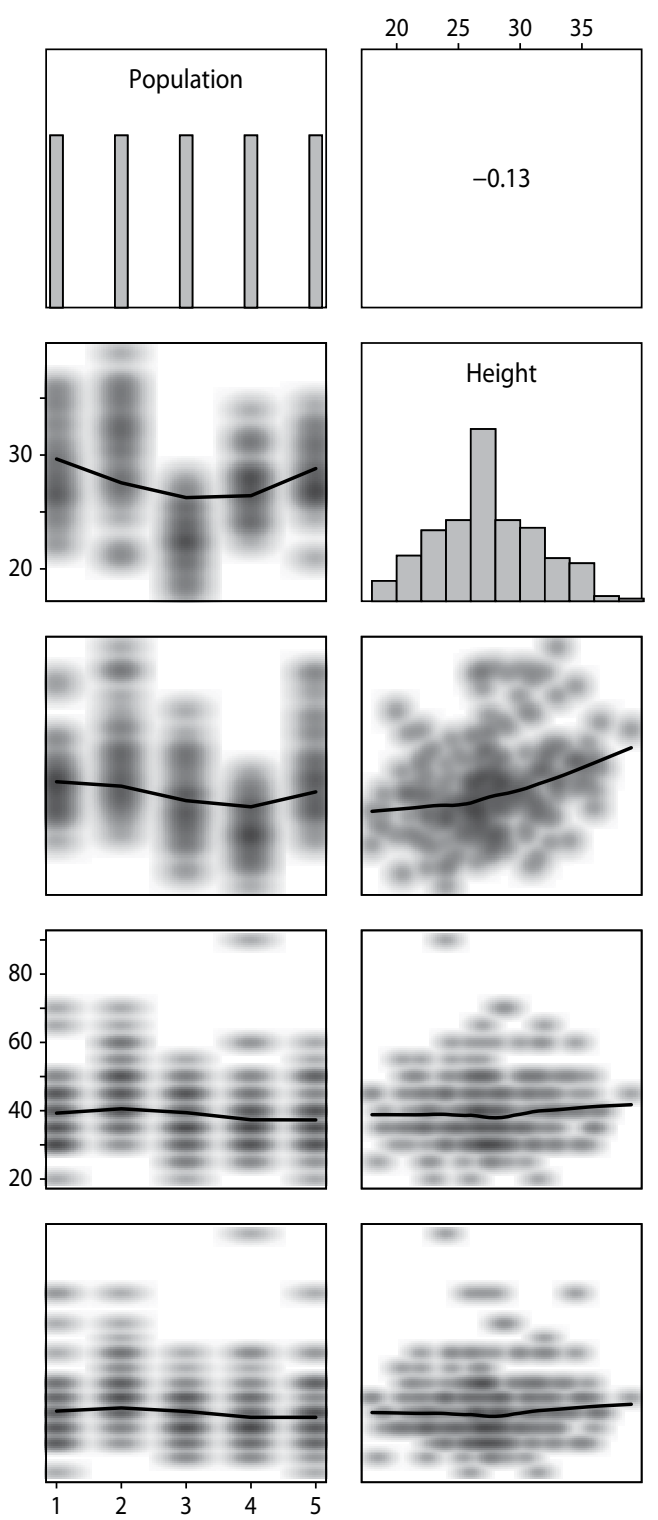
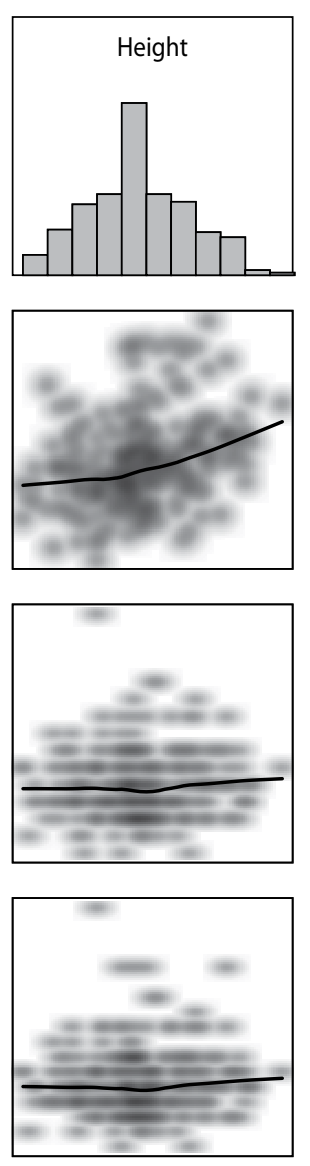
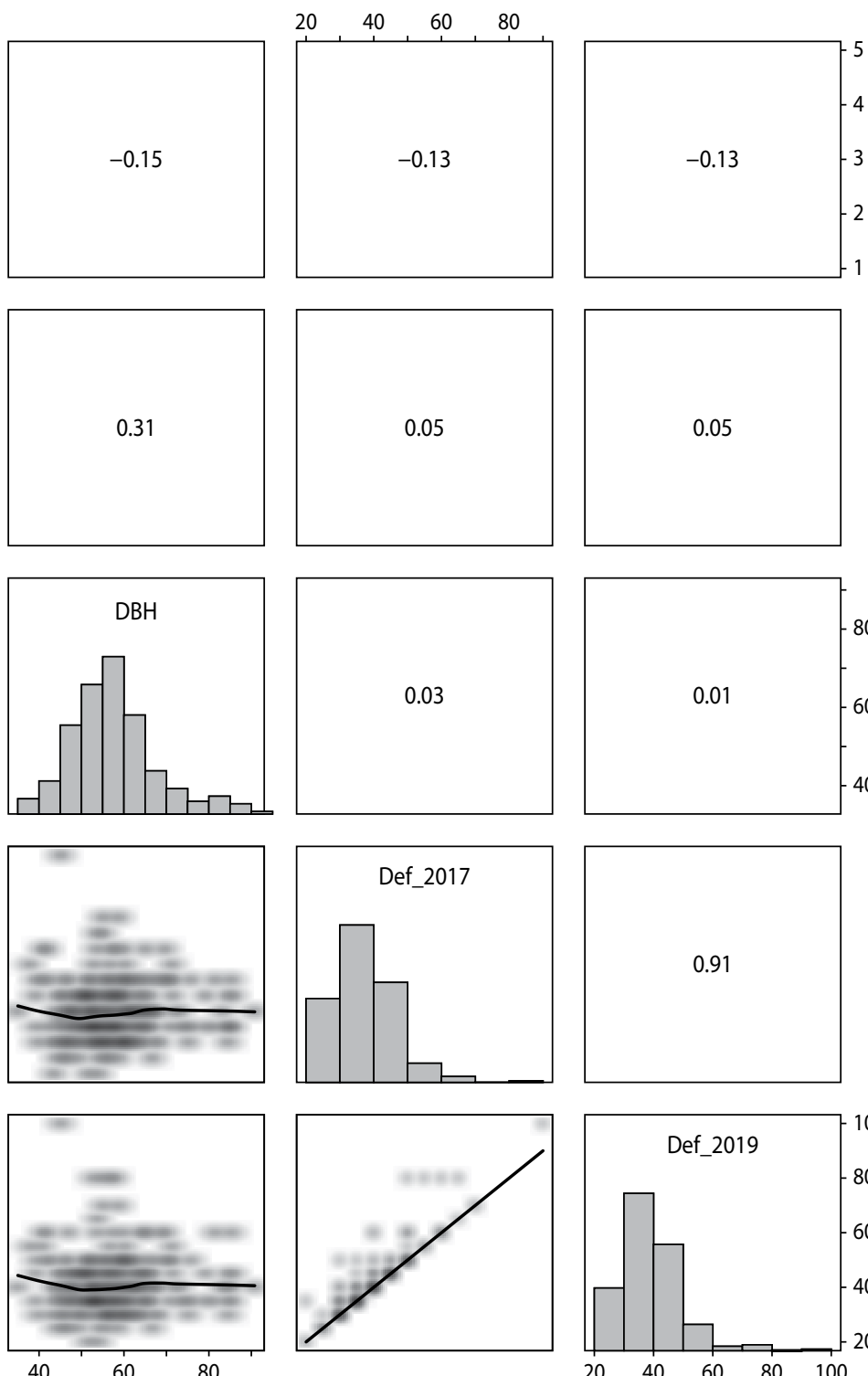
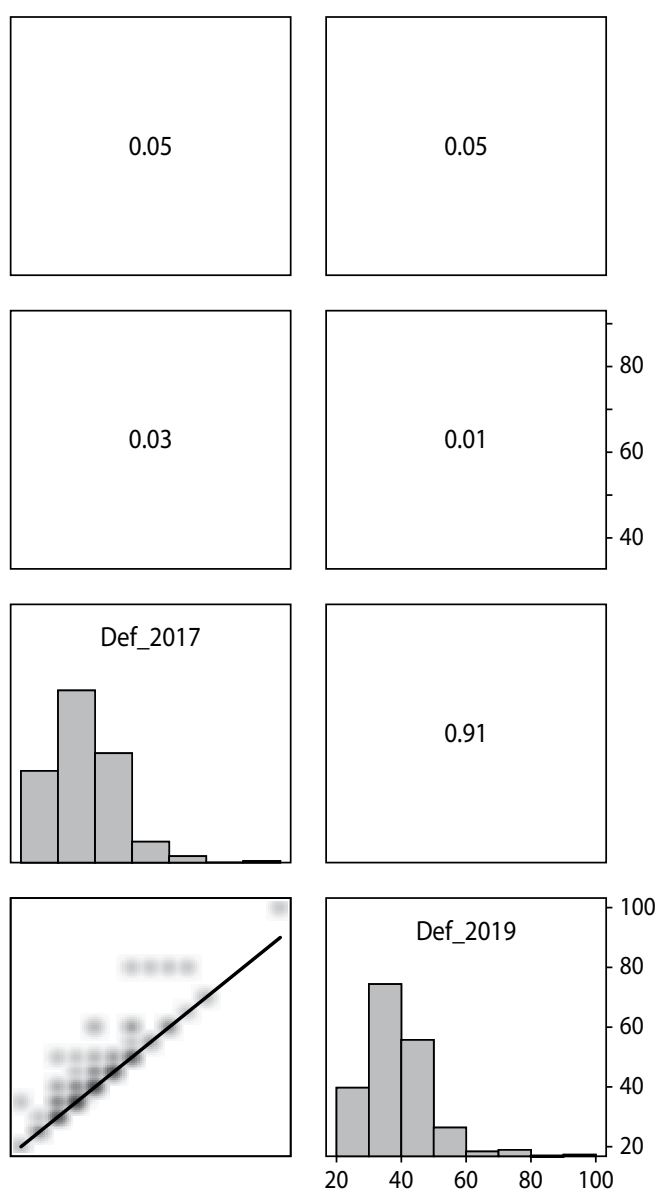

Figure 8. Correlations between the analysed features and populations in 2017 and 2019; populations: 1 - Czerwińskie G.; 2 - Granica; 3 - Sieraków; 4 - Wiersze; 5 - Wilków 
eter (Fig. 8). A significant correlation $(\mathrm{r}=0.91)$ was found between the levels of defoliation in 2017 and 2019 (Fig. 8). The results indicated a strong deterioration of the health of those trees having an initial (2017) level of defoliation exceeding $50 \%$ - in those trees, defoliation increased by about $20 \%$ (Fig. 8 ).

\section{Discussion}

Tree defoliation is one of the basic criteria of forest monitoring in Poland and Europe. This phenomenon depends on a tree's genotype, phenotype and external factors influencing the plant (Sierota 1995). Determining the level of defoliation is the most economical approach to determine the degree of damage in a stand (Wójcik 2000), hence the common use of the method. However, the appearance of the crown gives only a partial indication of tree health, as there are instances where trees with undamaged crowns are in poor health and where stands with heavily damaged crowns may be recovering. For the above reasons, when discussing the health of forest stands, a number of additional factors, such as stand age, habitat type and assessments of environmental and biotic stresses should be analysed.

Studies by Borecki and Wójcik (1996), Wójcik (2000), and Jaszczak (2003, 2005) conclude that age plays an important role in the health of forest stands. Younger populations, especially those up to 60 years old, usually show significantly less damage than older stands. Wójcik (2000), based on the results of research conducted in the Wyszków Forest District, found that older trees generally are most severely damaged, a result confirmed by Borecki and Wójcik (1996). It is noted that this trend is not always observed (e.g., Socha and Ochała 2002, Jaszczak and Miotke 2009). In these latter studies, the differences in health status between older and younger stands were statistically insignificant. The results of the present research did not indicate that age had a significant effect on the health of the stands evaluated. It is also worth noting that stands that were at least age class VII in this study were classified as undamaged using the Dmyterko formula (1994). The authors of the above analyses conclude that the lower density of a stand in age class IV and older is the reason why stand age does not influence the level of defoliation. In stands that are over 130 years old, the lower stand density means that competition for light is decreasing and that more light is available deeper into crown canopies.

In the present study, defoliation was significantly greater at Granica than the other stands. This difference is consistent in both years and, as a result, Granica is rated the most severely damaged stand. Trees at Granica are also the tallest and have the largest diameter. In 2019, the largest increase in crown damage was observed in the stand at Czerwińskie Góry, which is the stand with the second greatest height and diameter, after Granica. This trend suggests that allometric features are related to defoliation rate. However, when this relationship was tested by correlation analysis, considering all trees from across all sites, the correlation was not significant. We note that the sites at Granica and Czerwińskie Góry are the most fertile of those examined in this study, and that greater soil fertility resulted in larger trees at the same age. This result agrees with the study by Przybylski (1993), who concluded that on rich soils, pine's peak productivity and optimum vitality are reached at a younger age than on less fertile soils. Secondly, our results suggest that a relationship exists between stand damage and habitat. Borecki and Wójcik (1996) found a weak correlation between the loss of the assimilation apparatus and habitat, with a lower level of damage in the poorer habitat (mesic coniferous forest), compared to a richer habitat (mesic mixed forest). However, this trend is not confirmed by the results of Jaszczak (2000). The authors of this publication have examined a broader range of habitats and interpreted their results in relation to root system structures that develop under different environmental conditions, and how this relates to drought stress.

Root system architecture of Scots pine varies with habitat conditions (Mickovski and Ennos 2002). In fertile habitats, pine does not develop a taproot that penetrates deep into the soil. Therefore, trees from fertile habitats can be more vulnerable to drought stress as they do not exploit deeper soil layers. Additionally, once a pine tree reaches an age of 40 or more years, its root system form is largely unchangeable (Kalliokoski 2011), so that in the event of drought, such trees may be more susceptible to drought. When trees in fertile habitats are exposed to repeated episodes of drought, they therefore become weaker and experience repeated episodes of crown dieback. Water deficits affect many basic physi- 
ological processes of a tree, such as inhibition of sugar accumulation (Sierota 1995). As long-term drought increasingly weakens a tree, it can become more susceptible to infection by root pathogens, leading to a spiral model of disease (Sierota 1995). Kozlowski (1978) indicates that the effects of defoliation and drought result in cumulative stress in trees. In KNP, a significant water deficit was recorded in 2015 (Fig. 7), when annual precipitation was $406 \mathrm{~mm}$. This drought significantly decreased the health of stands (Tyburski and Przybylski 2018). In subsequent years, although precipitation was higher, 2018 was also considered a dry year, with annual precipitation of $506 \mathrm{~mm}$ (Fig. 7). From these observations, we conclude that crown dieback in this study reflects the effects of significant water deficits that most affected trees in fertile habitats where pine tree roots grew more shallowly. As a result, trees on fertile sites may have been unable to access water deeper in the soil. The second factor causing stress in the present study was crown dieback, strongly reducing the assimilation apparatus, and consequently, reducing the passive absorption of soil moisture. Precipitation events in 2016 and 2017 were intense but short-lived. Water was only available to plants for brief periods of time. Trees with a reduced assimilation apparatus probably failed to replenish water reserves as effectively as plants with lower defoliation. For these reasons, the present research indicates that trees growing in more fertile habitats and those that already have significant defoliation/crown dieback are more prone to experience higher levels of damage.

\section{Conclusion}

Defoliation, as a stand property, is subjectively evaluated by the researcher. It provides information about the current health of a stand, based on the percentage loss of the assimilation apparatus in relation to a reference tree. However, such information does not indicate the cause of the reduced health status and does not predict whether a tree or stand will continue to decline in health or recover. The findings of this research indicated that stands with the largest trees, indicated by greater heights and Dbh, had greater levels of crown damage. However, we rejected the hypothesis that larger trees were more susceptible to defolia- tion/crown dieback because when trees from the entire set of stands were evaluated by correlation analysis, the result was not significant. Instead, these results suggest that habitat fertility is related to the degree of stand damage, with trees from more fertile sites being more prone to crown dieback. We conclude that water deficit on fertile sites, where trees are larger, are more prone to crown dieback and damage to the tree assimilation apparatus.

Despite a significant increase in the level of defoliation/crown dieback from 2017 to 2019, the mature forest trees from the KNP examined in this study were classified as undamaged. This indicates that their health condition is satisfactory, which, based on their relatively old age and past exposure to water deficits, shows the significant natural value of these stands.

\section{ACKNOWLeDGement}

The research was carried out within the framework of the task 'The genetic characteristics of stands of the scots pine (Pinus sylvestris) in the Kampinos National Park - stage II', co-financed in 2018 by the forest fund of State Forests PGL.

\section{ReferenCes}

Borecki, T., Wójcik, R. 1996. Ocena stanu uszkodzenia drzewostanów Nadleśnictwa Krotoszyn. Sylwan, 7, 5-21.

Borowski, M. 1966. Uber den Zuwachs der sozialen Baumklassen in Kiefernbestanden. Archiv fur Forstwesen, 3, 233-241.

Dmyterko, E. 1994. Metody określenia stopnia uszkodzenia drzewostanów sosnowych przez emisje przemysłowe. Prace IBL, 782, 128-155.

Dobbertin, M., Brang, P. 2001. Crown defoliation improves tree mortality models. Forest Ecology and Management, 141, 271-284.

Dubravac, T. 2003. Dinamika rozvoja duzina krosanja hrasta luznjaka i obicnoga graba ovisno o prosnom promjeru i dobi. Radovi, 39 (1), 51-69.

Dubravac, T. 2005. Primjena digitalizacije krosanja i metode vizualizacije u izacavanju strukturę sastojina. Radovi, 40 (1), 53-72. 
Dudek, A. 1969. Zależność intensywności przyrostu miąższości i przyrostu pierśnicy od wielkości korony. Folia Forestalia Polonica Series A - Forestry, $15,149-469$.

Heymanowski, K. 1969. Rozwój sieci osadniczej w dobrach kampinoskich od połowy XV do połowy XIX wieku. Kwartalnik Historii Kultury Materialnej, 17 (2), 417-429.

Jaszczak, R. 1995. Zmiana stanu zdrowotnego drzewostanów sosnowych pod wpływem średnich skażeń $\mathrm{z}$ uprzemysłowionej aglomeracji miejskiej. Sylwan, $8,43-49$.

Jaszczak, R. 2000. Charakterystyka wskaźników uszkodzenia koron drzew sosny zwyczajnej różnych klas biosocjalnych. Sylwan, 144 (9), 65-76.

Jaszczak, R. 2001. Types of canopy opening and tree crown forms of Scots pine in the evaluation of stand condition. Scientific Papers of Agricultural University of Poznań. Forestry, 4, 31-41.

Jaszczak, R. 2003. The conditions of tree crowns of the mains stand of Scots pine in 2002 in some selected forest division of Poznan Regional Direction of State Forests. Scientific Papers of Agricultural University of Poznań. Forestry, 6, 11-22.

Jaszczak, R. 2005. Crown defoliation of Scots pine trees (Pinus sylvestris L.) of selected biosocial classes in forest monitoring . Roczniki Akademii Rolniczej w Poznaniu, Rozprawy Naukowe, 370, 5-127.

Jaszczak, R., Miotke, M. 2009. Defoliation of the top part and whole crown of Scots pine (Pinus sylvestris L.). Sylwan, 153 (9), 607-616.

Kalliokoski, T. 2011. Root system traits of Norway spruce, Scots pine and Silver birch in mixed boreal forests: an analysis of root architecture, morphology and anatomy. Academic disertation.

Kozlowski, T.T. 1978. Water deficits and plant growth. Vol. 5. Academic Press, New York.

Lech, P. 1995. Przydatność szacunkowej metody określania defoliacji drzew do badań stanu zdrowotnego lasu. Sylwan, 8, 99-107.

Lehner, B., Doll, P., Alcamo, J., Henrischs, T., Kaspar, F. 2006. Estimating the impact of global change on flood and drought risk in Europe: a continental, integrated analysis. Climatic Change, 75, 273-299.

Lemke, J. 1968. Zwiazek pomiędzy wielkością korony, a przyrostem drzew w drzewostanach sosnowych.
Prace Komisji Nauk Rolniczych i Komisji Nauk Leśnych. PTPN, 25, 1-48.

Mickovski, S., Ennos, A.R. 2002. A morphological and mechanical study of the root systems of suppressed crown Scots pine. Trees, 16, 274-280.

Mohamad, H. 1977. Długość koron drzew w drzewostanach sosnowych. Sylwan, 121 (1), 1-12.

Przybylski, T. 1993. Autekologia i synekologia. In: Biologia sosny zwyczajnej (eds.: S. Białobok, A. Boratyński, W. Bugała). Sorus, Poznań, 255-281.

R Core Team. 2018. R: A language and environment for statistical computing. R Foundation for Statistical Computing, Vienna, Austria. Available at https:// www.R-project.org/

Revelle, W. 2018. Psych: Procedures for Personality and Psychological Research, R Package Version 1.8.12. Available at https://CRAN.R-project.org/ package $=$ psych

Sierota, Z. 1995. Przerzedzenie koron drzew jako efekt stresu i źródło stresu. Sylwan, 8, 5-24.

Silva, L.J. 2015. Laercio: Duncan test, Tukey test and Scott-Knott test. R package Version 1.0-1. Available at https://CRAN.R-project.org/package $=$ laercio

Socha, J., Ochał, W. 2002. Tendencja wzrostowa wierzchołka i stopień defoliacji koron drzew w drzewostanach sosnowych wzrastających w wybranych regionach przemysłowych Polski południowej. Sylwan, 5, 53-59.

Turski, M., Beker, C., Jaszczak, R. 2015. Wydajność aparatu asymilacyjnego sosny zwyczajnej różnych klas wieku. Sylwan, 159 (1), 36-44.

Tyburski, Ł. 2015. Zróżnicowanie faz rozwojowych drzewostanów w Kampinoskim Parku Narodowym. In: Lasy w parkach narodowych i rezerwatach przyrody (eds.: D. Marczak, Ł. Tyburski), 185-191.

Tyburski, Ł., Przybylski, P. 2016. Health condition of the Scots pine (Pinus sylvestris) in Kampinos National Park - preliminary studies. Folia Forestalia Polonica, Series A - Forestry, 58 (4), 240-245.

Tyburski, Ł., Przybylski, P. 2018. Evaluation of the loss of the assimilation apparatus and its causes in Scots pine stands (Pinus sylvestris L.) of the Kampinos National Park. Folia Forestalia Polonica, Series A - Forestry, 60 (3), 173-182. 
Urban, J., Tatarinov, F., Nazdezhidina, N., Cermak, J., Ceulemans, R. 2009. Crown structure and leaf area of the understorey species Prunus serotina. Trees. Structure and Function, 23 (2), 391-399.

Wójcik, R. 2000. Analiza zmian ilościowych aparatu asymilacyjnego $\mathrm{w}$ drzewostanach sosnowych nadleśnictwa Wyszków. Sylwan, 144 (8), 39-46.
Zajączkowski, J. 1973. Przyrost miąższości w klasach biosocjalnych starszych drzewostanów sosnowych. Sylwan, 117,(1), 1-10.

Zgorzelski, M., Pawłowska, T. 2003. Geomorfologia. In: Kampinoski Park Narodowy. Przyroda Kampinoskiego Parku Narodowego. Tom I (ed.: R. Andrzejewski). Kampinoski Park Narodowy, Izabelin, 87-95. 